\title{
KONSEP PEMIKIRAN MERKANTILISME
}

Mirna Rafki/90100118012

Ekonomi Islam (A) 2018

Sistem ekonomi Merkantilisme diawali sejak abad ke-18. Sistem ekonomi merkantilisme ini mempunyai pemikiran bahwa Negara yang ingin maju maka harus melakukan perdagangan antar Negara atau menjalin hubungan kerja sama. Selanjutnya, kekayaan Negara kemudian akan diperoleh melalui surplus perdagangan antar Negara yang akan diterima dalam bentuk emas dan perak. Karenanya, kelompok saudagar dianggap memiliki posisi yang penting di dalam masyarakat. Sehingga di dalam praktek ekonomi banyak terjalin hubungan antar saudagar dan pengusaha, dimana antar saudagar tersebut saling memperkuat satu sama lain. Dengan hak istimewa yang diberikan oleh pengusaha kepada saudagar seperti, proteksi, monopoli serta keistimewaan lainnya. Sehingga pada abad ke-17 dan ke-18 M disebut sebagai zaman kapitalisme komersial atau kapitalisme saudagar.(Munif, 2015)

Masa merkantilisme ditandai sebagai periode dimana setiap orang menjadi pakar ekonomi untuk dirinya sendiri. Ada 3 (tiga) pokok aliran merkantilisme, ialah mekanisme neraca perdagangan arus logam mulia, proteksi serta teori kuantitas uang. Ketiga pemikiran tersebut terpusat pada paham merkantilisme, yakni neraca perdagangan yang menguntungkan. (Fatkhur Rahman Albanjari, 2017). Adapun tokoh-tokoh pemikir merkantilisme ialah:

\section{Jean Bodin (1530-1596)}

Jean Bodin ialah ilmuwan berkebangsaan prancis, meninggal pada bulan Juni 1596, di Laon. Ia biasa dikatakan selaku orang pertama yang menyajikan teori tentang uang dan harga, dimana harga sangat berorientasi pada keuntungan yang akan diperoleh.(Parakkasi, H. Idris, 2018). Seperti pada bukunya yang berjudul "Reponse Aux Paradoxes de Malestroit" ditulis bahwa naiknya harga barang disebabkan karena beberapa faktor salah satunya ialah bertambahnya logam mulia seperti emas dan perak. 


\section{Thomas Mun (1571 - 1641)}

Thomas Mun ialah saudagar yang berasal dari inggris. Ia dilahirkan di inggris pada 17 Juni 1571 dan meninggal 21 Juli 1641. Ia banyak menulis tentang perdagangan luar negeri. Mun ialah anggota kelompok pedagang inggris yang populer dan dihormati. Beberapa pendapat yang Mun keluarkan terkait dengan kebijakan harga, kebijakan pajak, dan kebijakan barang.

\section{Jean Baptiste Colbert (1619 - 1683)}

Jean Baptiste Colbert lahir di Reims, pada tanggal 29 agustus 1619 dan meninggal pada tanggal 6 september 1683. Colbert adalah pejabat Negara perancis sebagai menteri utama bidang ekonomi serta keuangan dalam pemerintahan Raja Louis XIV. Colbert berkerja dengan tujuan menciptakan kesimbangan perdagangan yang menguntungkan, serta juga Colbert lebih mengarah kepada kekuasaan dan kejayaan Negara dari pada untuk meningkatkan kekayaan orang-perorang.

\section{Sir William Petty $(1623-1687)$}

Sir William Petty lahir pada tanggal 26 Mei 1623 dan meninggal pada tanggal 16 Desember 1687, Ia adalah seorang ekonom, ilmuwan serta filsuf Inggris. Ia banyak mengemukakan teori ekonomi dan tata cara aritmatika politik. Selain itu Sir William pula diketahui sebagai ahli bahasa, dokter, ahli musik, pelaut, dan menjabat sebagai wakil direktur disuatu akademisi. Sir William juga berpikiran bahwa tenaga kerja (labor) lebih penting jika dibandingkan dengan sumber daya tanah (alam), selain itu menurutnya uang diperlukan dalam jumlah yang secukupnya saja.

\section{David Hume ( 1711 - 1776)}

David Hume lahir tanggal 26 April 1711 di Edinburgh Skotlandia. David Hume ialah teman dekat Adam Smith. Mereka kerap mendiskusikan pandangan-pandangannya tentang ekonomi. Dalam teorinya David Hume sangat memperhatikan faktor keadilan. Dalam bukunya "Of Balance Of Trade" ia banyak membicarakan tentang harga yang sebagian dipengaruhi oleh jumlah uang.(Faruq \& Mulyanto, 2017). 


\section{DAFTAR PUSTKA}

Faruq, U. Al, \& Mulyanto, E. (2017). Sejarah Teori-Teori Ekonomi (Issue 1).

Fatkhur Rahman Albanjari. (2017). Pemikiran Ilmu Ekonomi (Analisis Komparatif Ekonomi Masa Pra Klasik Dan Masa Rasulullah Saw). Jurnal Ekonomi Syariah Dan Bisnis, 4(1), 20-36.

Munif, N. A. (2015). Sistem Ekonomi Islam Dialektika Antara Thesis, Antitesis Dan Plagiatis. IAIN Tulungagung Research Collentions, 2(1), 319-348.

Parakkasi, H. Idris, Dan K. (2018). Analisis Harga Dan Mekanisme Pasar Dalam Perspektif Islam. Laa Maysir, 5(1), 112. 